\title{
Married or Civil Partner
}

National Cancer Institute

\section{Source}

National Cancer Institute. Married or Civil Partner. NCI Thesaurus. Code C150743.

An indication that an individual is in a legally recognized relationship with another person, with the same rights and responsibilities as a marriage. 